\title{
Kajian Awal Perencanaan Lajur Khusus Sepeda Dengan Menggunakan Metode IPA (Importance Performance Analysis) dan SWOT
}

\section{Preliminary Study of Special Bike Lane Planning Using the IPA (Importance Performance Analysis) and SWOT Method}

\author{
Agung Prasetyo ${ }^{1}$ Meriana Wahyu Nugroho ${ }^{2}$ Abdiyah Amudi ${ }^{3}$ Totok Yulianto ${ }^{4}$ \\ ${ }^{1234}$ Jurusan Teknik Sipil, Fakultas Teknik, Universitas Hayim Asy'ari, Tebuireng Jombang \\ Email : prasetya0986@gmail.com
}

\begin{abstract}
Abstrak
Perancangan fasilitas jalur sepedaa juga terkait dengan UU Nomor 38 Tahun 2004 tentang Jalan dan Undangundang Nomor 26 Tahun 2007 tentang Tata Ruang. Berdasarkan aspek legal tersebut, maka terdapat keharusan membangun lajur sepeda (Mulyadi, 2014). Dalam kajian lajur khusus sepeda terdapat beberapa analysis yaitu Level Of Service (LOS) yang digunakan untuk menilai volume dan kepadatan ruas jalan yang akan digunakan, menentukan nilai kelayakan ruas yang akan ditentukan. Selain Los Of Service LOS terdapat analysis Importance Performance Analysis (IPA) yang manfaatkan untuk menghitung hubungan antara pendapat konsumen dan keutamaan peningkatan kualitas produk/jasa yang dikenal pula sebagai quadrant analysis, lalu menggunakan analysis SWOT yang digunakan untuk mendapatkan aspek-aspek pokok dari kekuatan, kelemahan, peluang, dan ancaman di suatu kajian ruas jalan. Dari data analysis diatas mendapatkan nilai LOS baik pada jalan Diponegoro,RA Kartini dan Thamrin, sedangkan untuk analysis IPA terdapat nilai X 3.53, Y 3.76 pada jalan Diponegoro, nilai X 3.48, Y 3.76 pada jalan RA Kartini dan nilai X 3.76, Y 3.82 dijalan Thamrin. Pada analysis SWOT terdapat nilai ancaman yang sangat tinggi berupa kurangnya lahan sehingga tidak ada lahan bagi kendaraan berparkir dan PKL disepanjang jalan serta fasilitas yang kurang lengkap dan memadai.
\end{abstract}

Kata Kunci: Kajian awal lajur khusus seped; IPA; SWOT

\begin{abstract}
The design of lane facilities and bicycle lanes is also related to Law Number 38 of 2004 concerning Roads and Law Number 26 of 2007 concerning Spatial Planning. Based on this legal aspect, there is a need to build bicycle lanes (Mulyadi, 2014). In the study of special bicycle lanes, there are several analyzes, namely the Level Of Service (LOS) which is used to assess the volume and density of roads to be used, to determine the feasibility value of the sections to be determined. In addition to Los Of Service LOS, there is an Importance Performance Analysis (IPA) analysis usedTo measure the relationship between consumer perceptions and product / service quality improvement priorities, also known as quadrant analysis, then use a SWOT analysis which is used to find important aspects of strengths, weaknesses, opportunities and threats in a road segment study. From the data analysis above, the LOS values were obtained both on Jalan Diponegoro, RA Kartini and Thamrin, while for the IPA analysis there were $X$ values 3.53, Y 3.76 on Jalan Diponegoro, $X$ values 3.48, Y 3.76 on Jalan $R A$ Kartini and $X$ values 3.76, Y 3.82 on roads. Thamrin. In the SWOT analysis, there is a very high threat value in the form of a lack of land so that there is no land for parked vehicles and street vendors along the road and incomplete and inadequate facilities.
\end{abstract}

Keywords: Preliminary study for bicycle lanes; IPA; SWOT 


\section{PENDAHULUAN}

Pada umumnya kendaraan bermotor menjadi pilihan yang di gunakan sebagai sarana transportasi tapi tidak sedikit juga yang menggunakan kendaraan tidak bermotor. Khususnya bagi pengguna sepeda, sarana tersebut dianggap lebih hemat dan sehat karena tidak menggunakan bahan bakar dan mengeluarkan polusi udara. Pesepeda memiliki hak atas fasilitas pendukung keamanan, keselamatan, ketertiban dan kelancaraan dalam berlalu lintas (Pasal 62).

Dalam analisa Listtantari dan Joewono Soemardjito, (2017) tentang "Desain jalur sepeda di wilayah perkotaan wonosari kabupaten gunungkidul daerah istimewa Yogyakarta" menyatakan bahwa Menurut pandangan respon masyarakat desain fasilitas lajur kusus untuk sepeda di wilayah perkotaan Wonosari perlu pertimbangkan aspek keselamatan, kenyamanan, keamanan dan kelancaran dalam transportasi. Maka keterkaitan dalam penelitian ini adalah kajian awal yang akan dilakukan disekitar sekolah guna untuk menurunkan nilai kecelakaan terhadap lalu lintas dan kendaraam sepeda.

Dalam kajian lajur khusus sepeda terdapat beberapa analysis yaitu Level of Service (LOS) yang digunakan untuk menilai volume dan kepadatan ruas jalan yang akan digunakan, menentukan nilai kelayakan ruas yang akan ditentukan. Selain LOS terdapat analysis IPA (Importance Performance Analysis) yang manfaatkan untuk mengetahui hubungan antara pemikiran konsumen dan prioritas peningkatan kualitas produk/jasa yang dikenal pula sebagai quadrant analysis, lalu menggunakan analysis SWOT yang digunakan untuk menentukan pokok penting dari kekuatan, kelemahan, peluang, dan ancaman di dalam suatu kajian ruas jalan. Dari kajian lajur khusus sepeda memiliki tujuan untuk mengetahui nilai level pelayanan, mengetahui nilai IPA (Importance Performance Analysis) kemudian mengetahui strategi SWOT pada kajian lajur khusus sepeda agar memudahkan dalam perencanaan lajur khusus sepeda.

\section{TINJAUAN PUSTAKA}

\section{Kinerja Ruas Jalan}

Kapabilitas Jalan dalam Pedoman Kapabilitas Jalan Indonesia (PKJI,2017) terdapat metode untuk mengitung kapabilitas jalan di indonesia dengan rumus sebagai berikut :

$$
C=C_{O} \times F C_{L J} \times F C_{P A} \times F C_{H S} \times F C_{U K}
$$

Hambatan Samping dalam menentukan nilai Kelas hambatan samping digunakan rumus (PKJI 2017)

$S C F=P E D+P S V+E E V+S M V$

Derajat Kejenuhan adalah rasio arus lalu lintas (smp/jam) terhadap kapabilitas (smp/jam) pada bagian jalan tertentu.

$D S=Q / C$

Tabel 1.Level Layanan Jalan (LOS)

\begin{tabular}{lll}
\hline $\begin{array}{l}\text { Level of } \\
\text { service }\end{array}$ & $\begin{array}{l}\text { Tundaan } \\
(\mathrm{det} / \mathrm{smp})\end{array}$ & Keterangan \\
\hline A & $\leq 0,5$ & Baik sekali \\
B & $5,1-15$ & Baik \\
C & $15,1-25$ & Sedang \\
D & $25,1-40$ & Kurang \\
E & $40,1-60$ & Buruk \\
F & $\geq 60$ & Buruk sekali \\
\hline
\end{tabular}

(Sumber :PKJI 2017)

\section{Lajur Khusus Sepeda}

Dalam pasal 62 juga disebutkan bahwa pemerintah harus memberikan kemudahan berlalu lintas bagi pesepeda. Pesepeda berhak atas fasilitas pendukung keamanan, keselamatan, ketertiban, dan kelancaran dalam berlalu lintas.

Tipe Lajur Sepeda

- Lajur sepeda (Bike Path)

- Lajur Sepeda (Bike Lane)

- Lajur Sepeda (Bike Route)

Prestasi Ruang Bersepada

- Ruang Gerak Statis

Ruang gerak statis yaitu ruang yang dibutuhkan bagi sepeda dan pengemudinya pada saat sepeda tidak bergerak

- Ruang Gerak Dinamis

Ruang yang digunakan oleh pengendara sepeda untuk bermanuver dijalan saat berjalan sendirian maupun berdampingan.

\section{Metode IPA}

Metode ini menghubungkan level kepentingan (importance) suatu atribut yang dimiliki obyek tertentu dengan keadaan lapangan atau kinerja (performance) yang dirasakan oleh pengguna. Adapun rumus yang digunakan :

$$
\begin{aligned}
& T k_{i}=\frac{X_{i}}{Y_{i}} \times 100 \% \\
& T k i=\text { Level Kesesuaian Responden } \\
& X i \quad=\text { Nilai Kinerja } \\
& \text { Proteksi/Desember } 2020 \text { Volume } 2 \text { No. } 2
\end{aligned}
$$


$Y i=$ Nilai Kepentingan

(John Martila and John C. James yang dikutip oleh J. Supranto, 2006).

Langkah kedua yaitu menjumlahkan rata-rata level kepentingan dan level kepuasan untuk setiap item dari atribut dengan rumus:

$\bar{X}=\frac{\sum_{i=1}^{k} x_{i}}{n} ; \bar{Y}=\frac{\sum_{i=1}^{k} y_{i}}{n}$

$\overline{X_{l}}=$ kualitas rata-rata level kepuasan item ke-i

$\bar{Y}_{l}=$ kualitas rata-rata level kepentingan item ke-i

$\mathrm{n}=$ Jumlah responden/sampel

Langkah selanjutnya adalah menjumlahkan rata-rata level kepentingan dan level kepuasan untuk keseluruhan item dengan rumus:

$\overline{\overline{x_{l}}}=\frac{\sum_{i=1}^{k} \bar{x}_{l}}{p} ; \overline{\bar{y}_{l}}=\frac{\sum_{i=1}^{k} \bar{y}_{l}}{p}$

$\overline{\overline{x_{l}}} \quad=$ Hasil rata-rata kepuasan item

$\overline{\bar{y}_{l}} \quad=$ hasil rata-rata kepentingan item

$p \quad=$ Jumlah item

Maka grafik IPA dijadikan empat kuadran berdasarkan nilai pengukuran importance performance sebagaimana terlihat pada Gambar berikut :

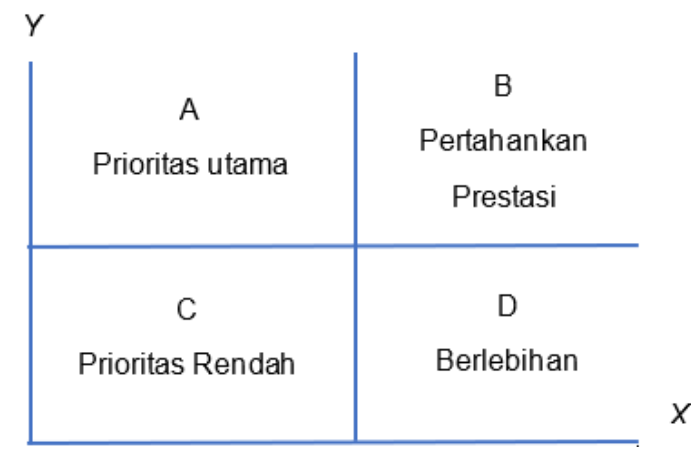

Gambar 1. Grafik IPA

(Sumber : Rangkuti; 2013)

\section{Metode SWOT}

Analisa SWOT adalah metode untuk mengidentifikasi segala hal faktor secara sistematis untuk meneumkan ide strategi perusahaan.

\section{Eksternal}

Peluang (opportunity)

Peluang merupakan sistuasi yang berkarakter baik dihadapi oleh suatu organisasi, yang apabila dapat digunakan akan besar fungsinya dalam mencapai tujuan organisasi
Ancaman/Hambatan (Threat)

Hambatan adalah halangan yang bersifat non baik yang diterima oleh suatu organisasi, yang apabila berhasil di atasi akan baik perannya dalam mendapatkan tujuan organisasi.

\section{Internal}

Kekuatan (Strength)

Kekuatan adalah kemampuan yang bersifat khas yang dimiliki oleh suatu organisasi.

Kelemahan (weakness)

Kelemahan adalah kekurangan yang bersifat khas yang dimiliki oleh suatu organisasi yang ketika diselesaiakn akan berdampak besar, tidak hanya dalam mempermudah berbagai kegiatan yang akan dikerjakan oleh organisasi.

\section{METODE}

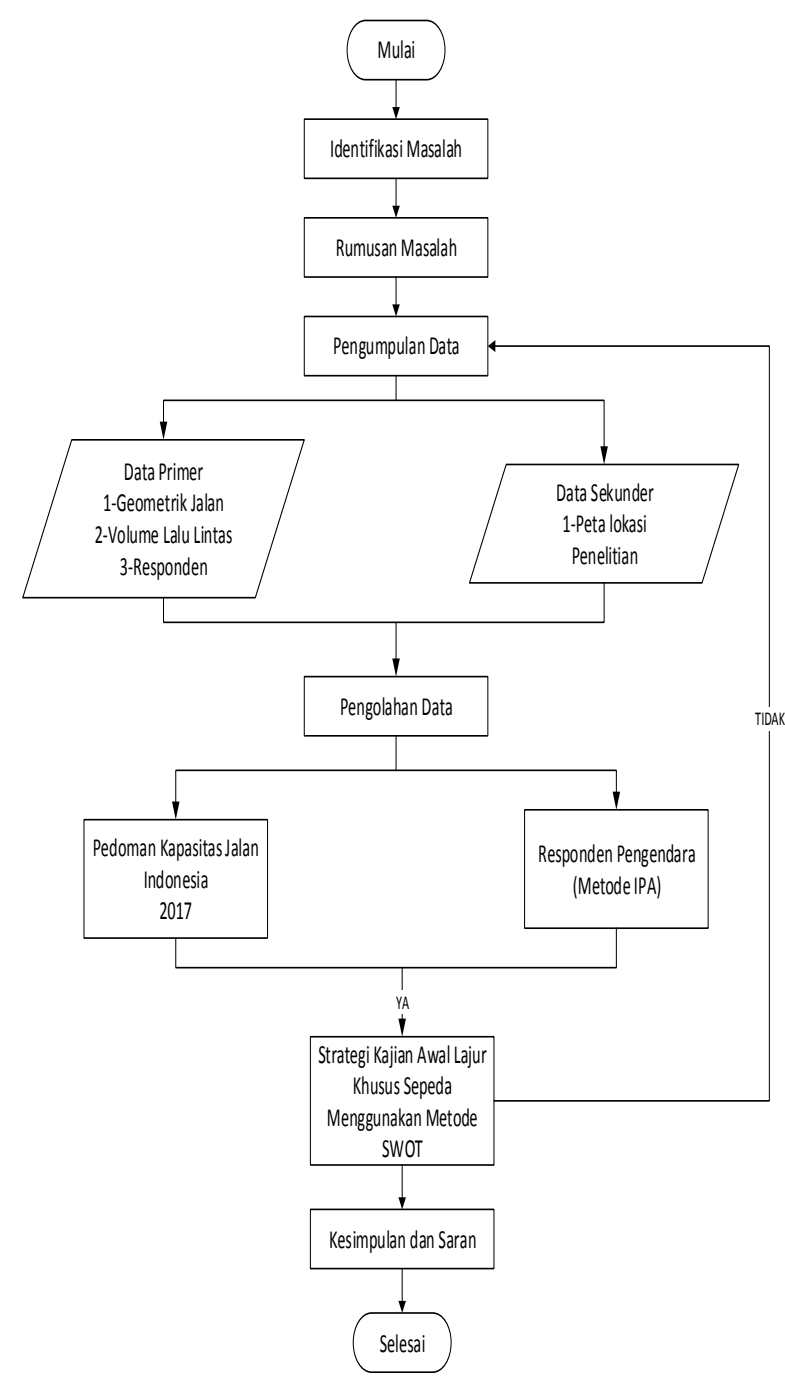

Gambar 2.Diagram Alir Penelitian

(Sumber : Penelitian, 2020)

Proteksi/Desember 2020 Volume 2 No. 2 


\section{HASIL DAN PEMBAHASAN}

Nilai Level Pelayanan

Jalan Diponegoro

Kapabilitas jalan kota dinilai dari kapabilitas dasar. Kapabilitas dasar adalah jumlah kendaraan maksimal yang dapat melewati suatu wadah pada suatu jalur atau jalan selama 1 jam. Pada jalan Diponegoro memiliki 2 jalur yaitu dari arah Barat ke Timur dan dari arah Timur ke Barat.

\section{Jalan RA Kartini}

RA Kartini berada pada simpang lima dikota madiun, jalan RA Kartini adalah jalan kota yang memiliki lebar jalan $9 \mathrm{~m}$ dan bahu jalan $2 \mathrm{~m}$. Kapabilitas jalan perkotaan dihitung dari kapabilitas dasar. Kapabilitas inti adalah jumlah kendaraan maksimal yang dapat melalui suatu penampang pada jalur selama 1 jam. Pada jalan RA Kartini memiliki 2 jalur yaitu dari arah Barat ke Timur dan dari arah Timur ke Barat.

\section{Jalan Thamrin}

Jalan Thamrin terdapat pada simpang bersinyal diponegoro, memilik arah laju dari selatan ke utara dan dari utara ke selatan Kapabilitas jalur perkotaan dinilai dari kapabilitas dasar.Kapabilitas pokok adalah jumlah kendaraan maksimal yang dapat melwati suatu penampang pada suatu jalur atau jalan selama 1 jam.

Adapun perhitungannya Nilai Level Pelayanan adalah sebagai berikut :

Tabel 1. Nilai Level Pelayanan

\begin{tabular}{lcc}
\hline \multicolumn{1}{c}{ Jalan } & C & DS \\
\hline Diponegoro & 3656,337 & 0,08 \\
RA Kartini & 3625 & 0,07 \\
Thamrin & 3769,42 & 0,08 \\
\hline
\end{tabular}

(Sumber: hasil penelitian,2020)

\section{Metode IPA}

\section{Jalan Diponegoro}

Sebelum mencari nilai level kecocokan total antara $\mathrm{X}$ (Kepuasan) dengan $\mathrm{Y}$ (Kepentingan) maka mencari nilai rata - rata item kepuasan dan kepentingan.

Langkah kedua yaitu taksiran rata-rata level kepentingan dan level kepuasan disetiap item dari atribut dengan rumus.

Tabel 2 Nilai IPA Jalan Diponegoro

\begin{tabular}{ccc}
\hline $\mathrm{TK}_{\mathrm{i}}$ & \multicolumn{2}{c}{$\sum$} \\
& $\mathrm{x}$ & $\mathrm{Y}$ \\
\hline 94,76 & 3.52 & 2,75 \\
\hline
\end{tabular}

(Sumber: hasil penelitian,2020)
Tabel diatas menjelaskan masing masing nilai rata rata terhadap titik kepuasan dan kepentingan dijalan Diponegoro kemudian di jadikan diagram kartesius.

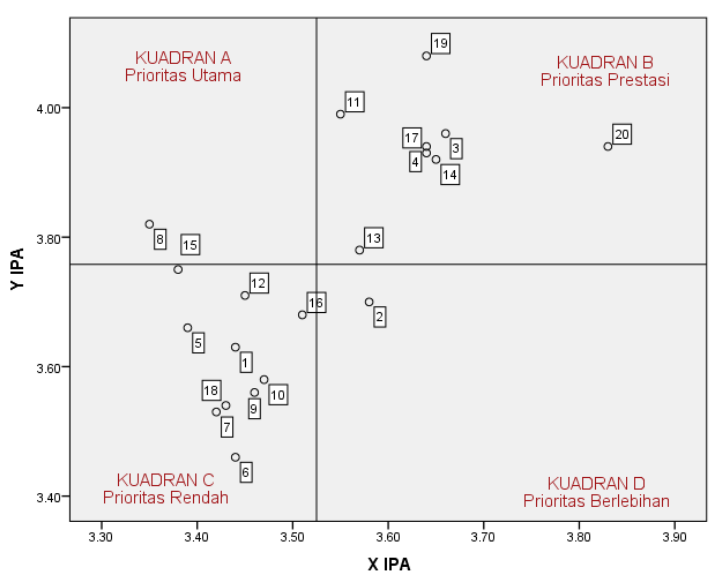

Gambar 3. Diagram Kartesius Jalan Diponegoro (Sumber: hasil penelitian,2020)

Jalan RA Kartini

Sebelum mencari nilai level kecocokan total antara $\mathrm{X}$ (Kepuasan) dengan $\mathrm{Y}$ (Kepentingan) maka mencari nilai rata - rata item kepuasan dan kepentingan.

Langkah kedua yaitu menaksir rata-rata level kepentingan dan level kepuasan untuk setiap item dari atribut dengan rumus.

Tabel 3 Nilai IPA Jalan RA Kartini

\begin{tabular}{|c|c|c|}
\hline \multirow[t]{2}{*}{$\mathrm{TK}_{\mathrm{i}}$} & \multicolumn{2}{|c|}{$\sum$} \\
\hline & $X$ & Y \\
\hline 92,09 & 3,47 & 3,61 \\
\hline
\end{tabular}

(Sumber: hasil penelitian,2020)

Tabel diatas menjelaskan masing masing nilai rata rata terhadap titik kepuasan dan kepentingan dijalan Diponegoro kemudian di jadikan diagram kartesius.

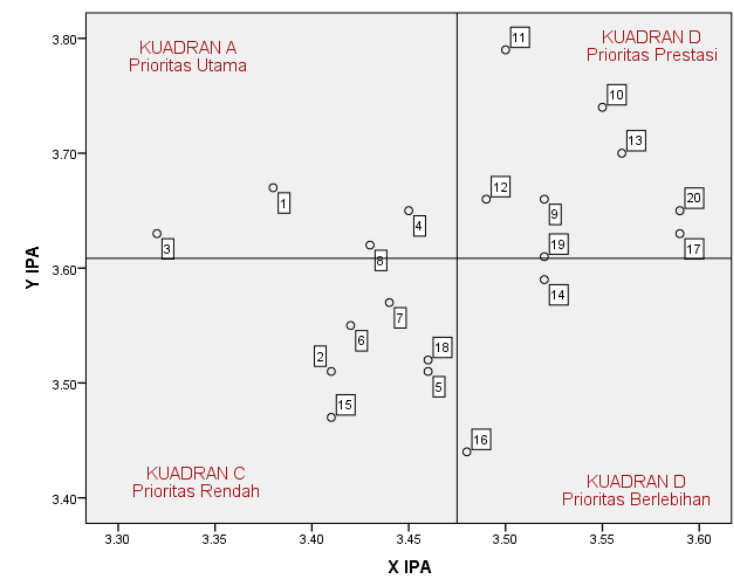

Gambar 4. Diagram Kartesius Jalan RA Kartini (Sumber: hasil penelitian,2020) 
Jalan Thamrin

Sebelum mencari nilai level kesesuaian total antara $\mathrm{X}$ (Kepuasan) dengan $\mathrm{Y}$ (Kepentingan) maka mencari nilai rata - rata item kepuasan dan kepentingan.

Langkah kedua yaitu menaksir rata-rata level kepentingan dan level kepuasan untuk setiap item dari atribut dengan rumus.

Tabel 4. Nilai IPA Jalan Thamrin

\begin{tabular}{ccc}
\hline $\mathrm{TK}_{\mathrm{i}}$ & $\mathrm{X}$ & $\mathrm{y}$ \\
& 3,76 & 3,81 \\
\hline 98,09 &
\end{tabular}

(Sumber: hasil penelitian,2020)

Tabel diatas menjelaskan masing masing nilai rata rata terhadap titik kepuasan dan kepentingan dijalan Diponegoro kemudian di jadikan diagram kartesius.

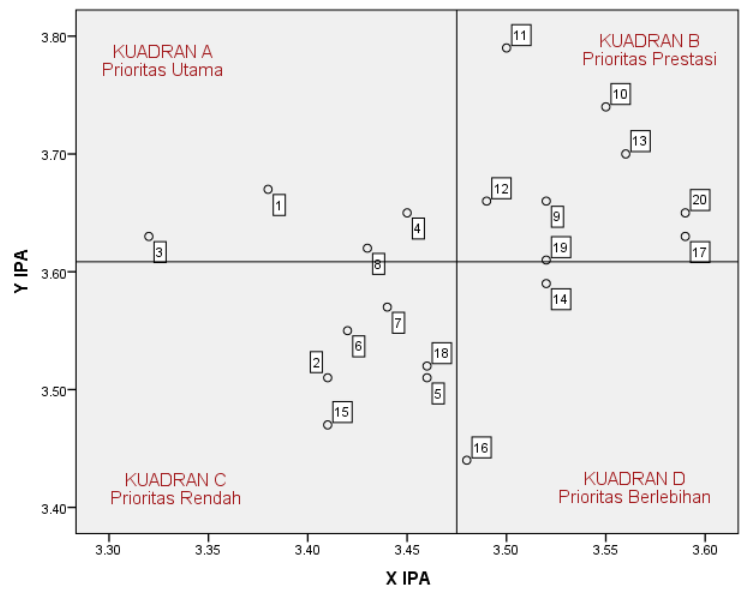

Gambar 5. Diagram Kartesius Jalan Thamrin (Sumber: hasil penelitian,2020)

\section{Analisis SWOT}

SWOT untuk rekognisi berbagai aspek secara sistematis untuk merumuskan strategi pembuatan lajur sepeda. Analisis SWOT hanya memperkiakan keadaan yang terjadi bukan sebagai pemecah masalah, bagaimana kekuatan (strengths) mampu menemukan keuntungan (advantage) dari peluang (opportunities) yang ada, bagaimana cara menghadapi kelemahan (weaknesses) yang mengatasi keuntungan (advantage) dari peluang (opportunities) yang ada, selanjutnya bagaimana kekuatan (strengths) mampu menerjang ancaman (threats) yang ada, dan terakhir adalah bagaimana cara memecahkan kelemahan (weaknesses) yang mampu membuat ancaman (threats) menjadi nyata
Tabel 5.SWOT Jalan Diponegoro

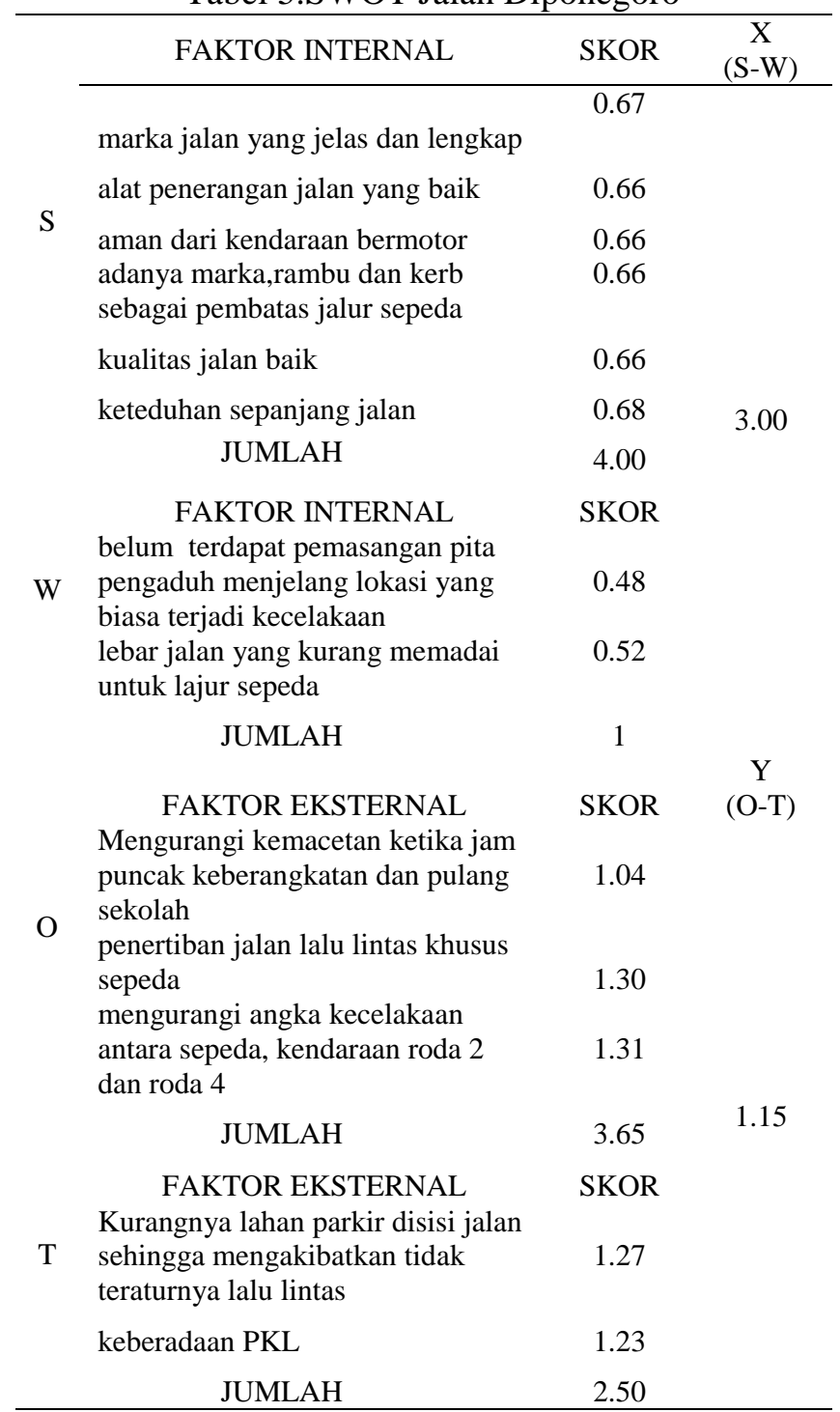

(Sumber: hasil penelitian,2020)

Tabel 6.SWOT Jalan RA Kartini

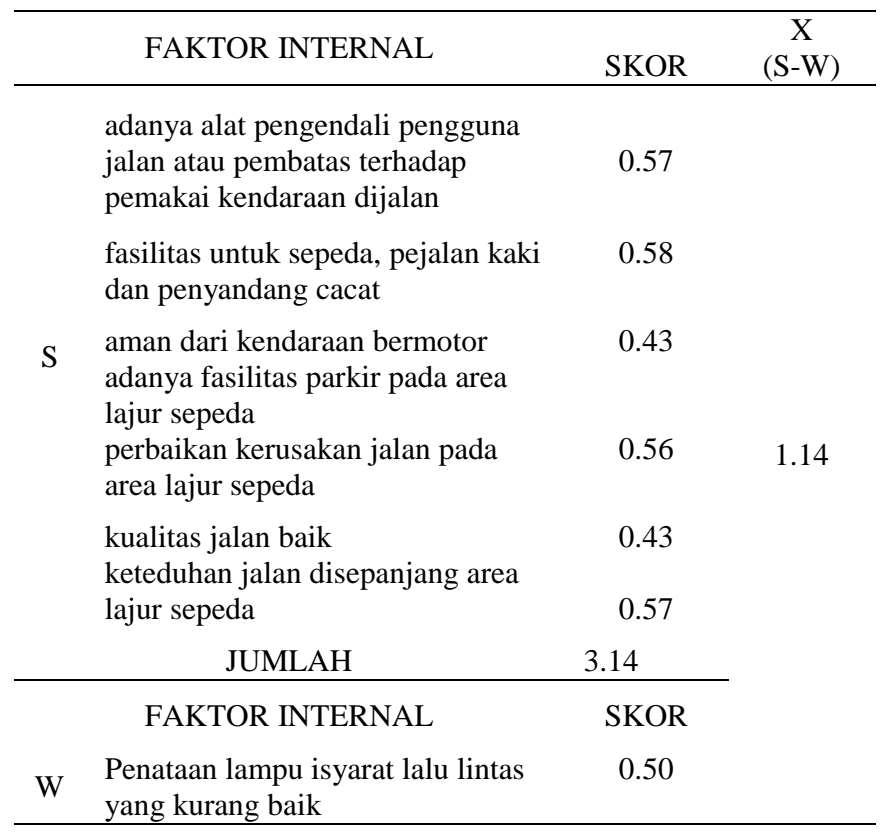




\begin{tabular}{|c|c|c|c|}
\hline & $\begin{array}{l}\text { marka jalan yang belum jelas dan } \\
\text { belum lengkap }\end{array}$ & $\begin{array}{l}0.49 \\
0.50\end{array}$ & \\
\hline & $\begin{array}{l}\text { alat penerangan yang belum baik } \\
\text { belom adanya pemasangan pita } \\
\text { pengaduh menjelang lokasi } \\
\text { berpoyensi terjadinya kecelakaan }\end{array}$ & 0.50 & \\
\hline & JUMLAH & 2.00 & \\
\hline \multirow{4}{*}{$\mathrm{O}$} & FAKTOR EKSTRNAL & SKOR & $\begin{array}{c}\mathrm{Y} \\
(\mathrm{O}-\mathrm{T})\end{array}$ \\
\hline & $\begin{array}{l}\text { adanya marka, rambu dan kerb } \\
\text { sebagai pembatas jalur area lajur } \\
\text { sepeda }\end{array}$ & 2.03 & \multirow{6}{*}{2.00} \\
\hline & perkkerasan lajur sepeda & 1.97 & \\
\hline & JUMLAH & 4.00 & \\
\hline \multirow{3}{*}{$\mathrm{T}$} & FAKTOR EKSTRNAL & SKOR & \\
\hline & keberadaan PKL dilajur sepeda & 2.00 & \\
\hline & JUMLAH & 2.00 & \\
\hline
\end{tabular}

(Sumber: hasil penelitian,2020)

Tabel 7.SWOT Jalan Thamrin

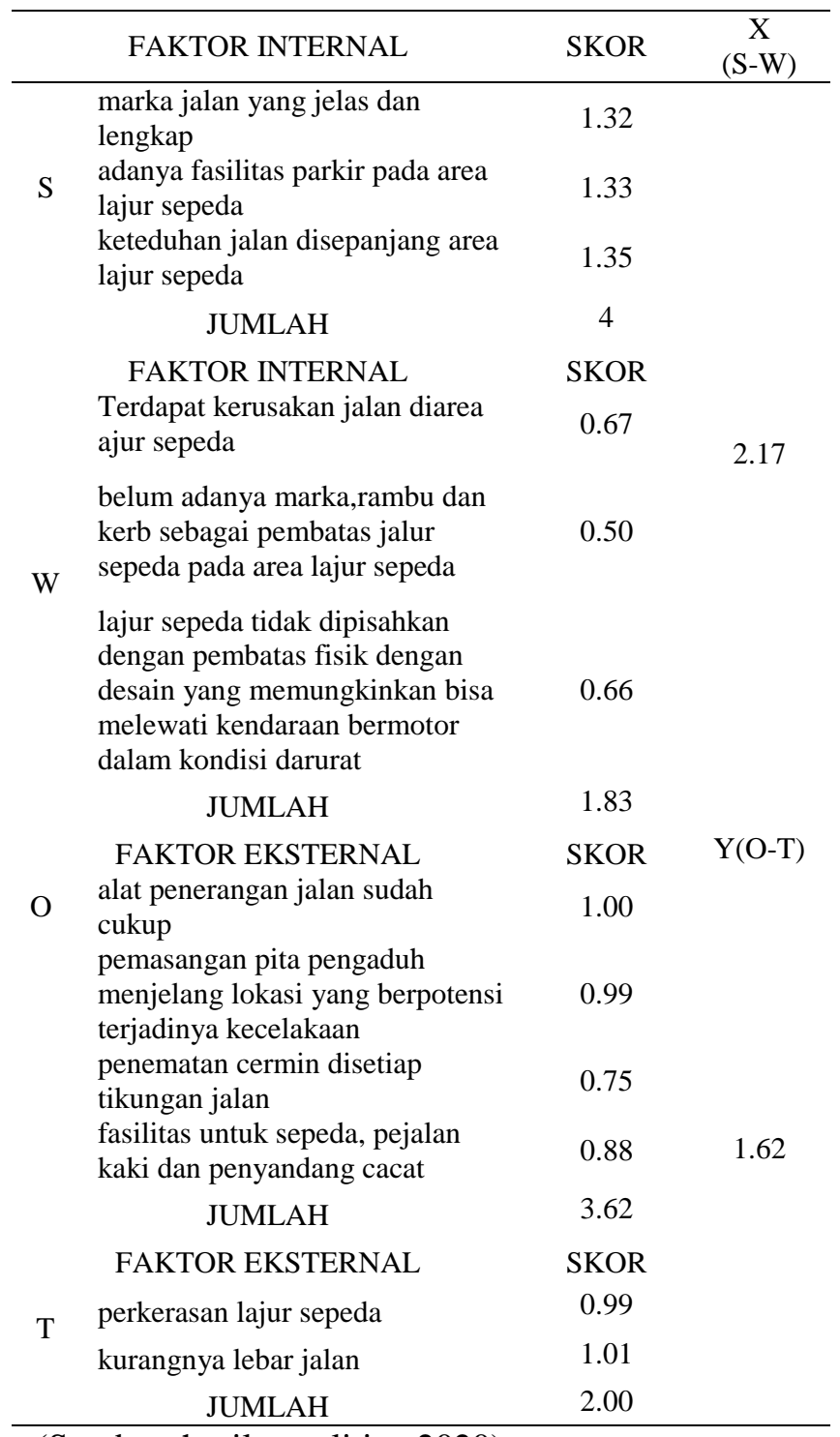

(Sumber: hasil penelitian,2020)

\section{Analisis Kelayakan}

Dari pengumpulan data diatas dan dilakukan analisa data maka mendapatkan hasil terhadap kajian awal lajur khusus sepeda dikota madiun pada ruas jalan Diponegoro, jalan RA Kartini dan jalan Thamrin. Adapun hasilnya dibawah ini :

Tabel 8. Analisis Kelayakan

\begin{tabular}{lcccc}
\hline \multirow{2}{*}{ Jalan } & \multicolumn{3}{c}{ Indikator } & Kesimpulan \\
& Los & IPA & SWOT & \\
\hline Diponegoro & A & 3.64 & 48.20 & Tidak Layak \\
RA Kartini & A & 3.54 & 49.90 & Layak \\
Thamrin & A & 3.79 & 45.79 & Tidak Layak \\
\hline
\end{tabular}

(Sumber: hasil penelitian,2020)

Dari tabel matrik diatas dijelaskan bahwa dijalan diponegoro tidak layak dalam kajian lajur khusus sepeda dengan alasan kurangnya lahan dalam perencanaan lajur khusus sepeda, Dijalan RA Kartini dijelaskan bahwa kajian awal lajur khusus sepeda dinyatakan layak dalam perencanaan lajur khusus sepeda, dijalan Thamrin dijelaskan bahwa jalan tersebut tidak layak apabila dilakukan perencanaan karena kurangnya lahan dan perkerasan jalan.

\section{SIMPULAN}

\section{Nilai Level Pelayanan}

\begin{tabular}{lcc}
\hline \multicolumn{1}{c}{ Jalan } & \multicolumn{2}{c}{ Level Of Service } \\
\hline Diponegoro & A & 0,14 \\
RA Kartini & A & 0,07 \\
Thamrin & A & 0,18 \\
\hline
\end{tabular}

(Sumber: hasil penelitian,2020)

\section{Nilai IPA}

Dari hasil kuisioner yang dibagikan dan wawancara yang dilakukan terhdap responden atau pengguna sepeda maka terdapat hasil tanggapan pengendara sepeda yakni:

\section{Jalan Diponegoro}

Tanggapan Kepentingan bagi pengguna sepeda terhadap Aspek kelengkapan jalan dan Aspek keselamatan dan kenyamanan lajur sepeda yaitu $88 \%$ dan tanggapan tidak penting $12 \%$.

Tanggapan Kepuasan bagi pengguna sepeda terhadap Aspek kelengkapan jalan dan Aspek keselamatan dan kenyamanan lajur sepeda yaitu 87\% dan tidak puas $13 \%$.

Jalan RA Kartini 
Tanggapan Kepentingan bagi pengguna sepeda terhadap Aspek kelengkapan jalan dan Aspek keselamatan dan kenyamanan lajur sepeda yaitu $78 \%$ dan tanggapan tidak penting $22 \%$.

Tanggapan Kepuasan bagi pengguna sepeda terhadap Aspek kelengkapan jalan dan Aspek keselamatan dan kenyamanan lajur sepeda yaitu $78 \%$ dan tidak puas $22 \%$.

Jalan Thamrin

Tanggapan Kepentingan bagi pengguna sepeda terhadap Aspek kelengkapan jalan dan Aspek keselamatan dan kenyamanan lajur sepeda yaitu $86 \%$ dan tanggapan tidak penting $14 \%$.

Tanggapan Kepuasan bagi pengguna sepeda terhadap Aspek kelengkapan jalan dan Aspek keselamatan dan kenyamanan lajur sepeda yaitu $88 \%$ dan tidak puas $12 \%$.

\section{Strategi Lajur Khusus Sepeda}

\section{Jalan Diponegoro}

Dari hasil analisis mendapatkan nilai $\mathrm{X}(3,00)$ dan Y $(1,15)$ dan ketika ditarik garis maka ditemukan titik pada KUADRAN $\mathrm{C}$ yang memiliki nilai $\mathrm{X}$ Negatif dan Y negative yakni prioritas rendah atau lemah maka strategi yang digunakan adalah Bertahan. Dengan demikian pembuatan lajur khusus sepeda dijalan Diponegoro belum memadai dikarenakan masih lemahnya nilai kebutuhan dan kepentingan yang dirasakan oleh pengguna sepeda dengan nilai level strategi SWOT yaitu 48,20\% yang artinya masih dibawah rata - rata.

\section{Jalan RA Kartini}

Dari hasil analisis mendapatkan nilai $\mathrm{X}(1,14)$ dan Y $(2,00)$ dan ketika ditarik garis maka ditemukan titik pada KUADRAN $\mathrm{C}$ yang memiliki nilai $\mathrm{X}$ Negatif dan Y negatif, yakni prioritas rendah atau lemah maka strategi yang digunakan adalah Bertahan. Dengan demikian pembuatan lajur khusus sepeda dijalan RA Kartini belum memadai dikarenakan masih lemahnya nilai kebutuhan dan kepentingan yang dirasakan oleh pengguna sepeda dengan nilai level strategi SWOT yaitu 49,80\% yang artinya masih dibawah rata - rata.

Jalan Thamrin

Dari hasil analisis mendapatkan nilai $X(2,17)$ dan $\mathrm{Y}(1,62)$ dan ketika ditarik garis maka ditemukan titik pada KUADRAN $\mathrm{C}$ yang memiliki nilai $\mathrm{X}$ Negatif dan Y negatif, yakni prioritas rendah atau lemah maka strategi yang digunakan adalah Bertahan. Dengan demikian pembuatan lajur khusus sepeda dijalan Thamrin belum memadai dikarenakan masih lemahnya nilai kebutuhan dan kepentingan yang dirasakan oleh pengguna sepeda dengan nilai level strategi SWOT yaitu $45,79 \%$ yang artinya masih dibawah rata - rata.

\section{REFRENSI}

Amudi, Abdiyah dkk. 2015. Evaluasi Kinerja Lajur Khusus Sepeda Dan Becak Di Jalan KH.Wahid Hasyim Kabupaten Jombang.Jurnal Rekayasa Sipil/Volume 9 No 2-2015 ISSN 19785658.https://rekayasasipil.ub.ac.id/index.ph p/rs/article/view/309.Diakses tanggal 7 Agustus 2019.

Azhar,Hada Mahadani. 2018. "Analisis Pengukuran Level Kepuasan Penumpang Pada Tryaek Bus Yogyakarta - Denpasar Menggunakan Metode Service Quality Dan Importance Performance Analysis (IPA)'.'Universitas Islam Indonesia. Yogyakarta.

Departemen Pekerjaan Umum Direktorat Jendral Bina Marga, Undang - undang Republik Indonesia Nomor 22 Tahun 2009 Tentang Lalu Lintas dan Anagkutan Umum. Sekretariat Negara.Jakarta.

Direktorat Jendral Bina Marga. 1990. Panduan Penentuan Klasifikasi Fungsi Jalan Di Wilayah Perkotaan.Jakarta

Hikaman, Asep Akbar dkk. 2014. Evaluasi Efektifitas Implementasi Lajur Sepeda Motor (Studi Kasus Jalan Raya Darmo Kota Surabaya).Jurnal Rekayasa Sipil/Volume 8 No 3.https://rekayasasipil.ub.ac.id .Dikases tanggal 6 Agustus 2019.

Kemenhub.Menteri Perhubungan Rebuplik Indonesia Nomor PM 16.2016.Tentan Penerapan Rute Aman Selamat Sekolah.

Menteri Perhubungan Republik Indonesia Nomor PM 16.2016.Tentang Penerapan Rute Aman Selamat Sekolah (RASS).

Peraturan Daerah Kota Madiun Nomor 06.2011.Tentang Rencana Tata Ruang Wilayah Kota Madiun Tahun 20102030.Kota Madiun. 